\title{
Digestible tryptophan requirements for broilers from 22 to 42 days old ${ }^{1}$
}

\section{Karina Ferreira Duarte ${ }^{2}$, Otto Mack Junqueira ${ }^{3,4}$, Rosemeire da Silva Filardi ${ }^{3}$, Jefferson Costa de Siqueira ${ }^{5}$, Maíra Mangili Puzotti ${ }^{6}$, Edivaldo Antônio Garcia ${ }^{7}$, Andrea de Britto Molino Antonio Carlos de Laurentiz ${ }^{3}$}

\author{
${ }^{1}$ Financed by FAPESP (2005/55549-0 and 2005/56680-3). \\ ${ }^{2}$ Faculdade de Ciências Agrárias e Veterinárias, Universidade Estadual Paulista "Júlio de Mesquita Filho", Jaboticabal, SP, Brasil. \\ ${ }^{3}$ Faculdade de Engenharia, Universidade Estadual Paulista "Júlio de Mesquita Filho", Ilha Solteira, SP, Brasil. \\ ${ }^{4}$ Universidade Federal de Goiás, Jataí, GO, Brasil. \\ ${ }^{5}$ Centro de Ciências Agrárias e Ambientais, Universidade Federal do Maranhão, Chapadinha, MA, Brasil. \\ ${ }^{6}$ Universidade Estadual de Maringá, Maringá, PR, Brasil. \\ ${ }^{7}$ Faculdade de Medicina Veterinária e Zootecnia, Universidade Estadual Paulista "Júlio de Mesquita Filho", Botucatu, SP, Brasil.
}

\begin{abstract}
The objective of this experiment was to establish different criteria to evaluate the requirements of digestible tryptophan for broilers from 22 to $42 \mathrm{~d}$ of age, using different regression models (quadratic, exponential and Linear Response Plateau) and in case of statistical significance the comparison of means by Duncan test at $5 \%$ probability was also adopted. A total of 1,920 Cobb 500 male broilers were distributed in a completely randomized experimental design, with 6 treatments ( 6 digestible tryptophan levels: $0.1395,0.1610,0.1825,0.2040,0.2255$ and $0.2470 \%$ ) and 8 replications containing 40 broilers each. Performance and carcass characteristics were evaluated. The level of $0.2255 \%$ of digestible tryptophan numerically improves feed conversion, and the $0.1919 \%$ estimated by the quadratic equation significantly improves carcass yield.
\end{abstract}

Key Words: digestible amino acids, ideal protein, performance, regression analysis

\section{Introduction}

Among other essential amino acids, tryptophan stands out for participating in protein synthesis and being a precursor of serotonin, which is related to the stimulation of feed intake (Henry et al., 1992) and lower stress before slaughter. According to Kidd \& Hackenhaar (2006), tryptophan deficiency not only affects carcass quality for participating in the synthesis of body protein but it also impairs the synthesis of important neurotransmitters such as serotonin and melatonin. This deficiency can be avoided if a rate or ratio to lysine of $17 \%$ or more is established in the diet formulation.

Tryptophan belongs to the class of essential amino acids, i.e., not produced by the animal or produced too slow, not meeting the animal requirements. Depending on the diet, it can be considered as a third limiting amino acid for poultry, followed by methionine and lysine (Peganova et al., 2003). It can be supplemented in diets, in the industrial form, L-tryptophan, with $99.3 \%$ digestibility for poultry. Its supplementation is currently not economically viable, since diets composed of corn and soybean meal normally have adequate amounts of this amino acid. Its supplementation is indicated in the case of alternative tryptophan-deficient ingredients and in diets based on the ideal protein, because it offers nutritionists the possibility to balance the diet, providing greater flexibility in their formulation (Kidd \& Hackenhaar, 2006).

In Brazil, feed industries use by-products of grain and animal origin on a large scale, mainly meat-and-bone meal, corn gluten meal and wheat bran in feed formulations, replacing corn and soybean meal. Amino acids in animal meals are not as digestible as those present in soybean meal (Pupa, 1995). According to Colnago (1992), the increased use of alternative feed sources of crude protein for broilers, coupled to the availability of industrial tryptophan competitively priced in the market, has stimulated research to better define the requirements of tryptophan for growing broilers.

Therefore, the objective of this study was to evaluate digestible tryptophan requirements for broilers from 22 to 42 days old.

\section{Material and Methods}

The experiment was conducted between the 22nd and 42nd days of the age of birds. A total of 1,920 one-day-old Cobb 500 male chicks were housed in a masonry poultry house with 80 pens.

The initial heating was provided by $250-\mathrm{W}$ infrared lamps, in order to maintain the temperature between 28 
and $30{ }^{\circ} \mathrm{C}$ during the first two weeks. The chicks were vaccinated against Marek, Gumboro and Bouba disease in the hatchery, followed by vaccination at 5 and 21 days against Gumboro disease and on the 8th day against Newcastle disease.

The litter was made from wood shavings and the amount placed in each pen was $1.2 \mathrm{~kg}$ of dry matter/bird housed, so that all treatments had the same initial amount of material used as litter at a height of $5 \mathrm{~cm}$. The lighting schedule used was 24 hours of light throughout the experimental period. During the entire experimental period, the birds received feed and water ad libitum.

During the initial period (1-21 days old), the birds were reared in an experimental shed, fed diets with $3,005 \mathrm{kcal}$ $\mathrm{ME} / \mathrm{kg}$ and $21.6 \% \mathrm{CP}$, to meet their nutritional requirements, according to the mean of the recommendations by Rostagno et al. (2005) for phases 1 to 7 and 8 to 21 days of age. At the end of the 21st day of age, the broilers were weighed, selected according to the criterion of average weight of each pen (750 \pm 35 grams) and distributed in a completely randomized design involving six treatments (levels of digestible tryptophan) with eight replications of 40 birds each.

The nutritional recommendations of crude protein, metabolizable energy, calcium, available phosphorus and digestible amino acids used in the experimental diets were established by Rostagno et al. (2005) through the means of recommendations for phases 22 to 33 and 34 to 42 days of age.

Chemical analysis of the ingredients used in the experimental diets (Table 1) were performed, according to the methodology described by Silva (1990). The metabolizable energy (ME) and digestibility coefficients used were those established by Rostagno et al. (2005).

To formulate a basal diet deficient in digestible tryptophan, it was necessary to include gelatin (acquired from the GELITA South America group) as an ingredient. The gelatin was made from skins (swine and bovine) and bones of slaughtered animals and approved for human consumption, with the collagen being the true raw material for its manufacture. About one-third of the acidic amino acids (glutamic and aspartic acid) is presented in the amide form, as glutamine and asparagine. Methionine was the only sulfur amino acid, but at small rates. Cysteine and tryptophan were completely absent.

Treatments consisted of a basal diet deficient in tryptophan, formulated based on digestible amino acids, according to the ideal protein concept, from 22 to 42 days of age, supplemented with five different digestible tryptophan levels, using $0.7642 \%$ of digestible threonine, according to Duarte (2009).

Table 1 - Chemical analysis and composition in total (TAA) and digestible (DAA) amino acids of the ingredients of experimental diets

\begin{tabular}{|c|c|c|c|c|c|c|c|c|}
\hline & \multicolumn{2}{|c|}{ Corn } & \multicolumn{2}{|c|}{ Soybean meal } & \multicolumn{2}{|c|}{ Gelatin $^{3}$} & \multicolumn{2}{|c|}{ Corn gluten meal $60 \%$} \\
\hline Dry matter & \multicolumn{2}{|c|}{88.90} & \multicolumn{2}{|c|}{89.10} & \multicolumn{2}{|c|}{100.00} & \multicolumn{2}{|c|}{90.60} \\
\hline Crude protein & \multicolumn{2}{|c|}{8.11} & \multicolumn{2}{|c|}{44.40} & \multicolumn{2}{|c|}{87.60} & \multicolumn{2}{|c|}{62.35} \\
\hline Metabolizable energy (kcal/kg) & \multicolumn{2}{|c|}{3381} & \multicolumn{2}{|c|}{2256} & \multicolumn{2}{|c|}{2874} & \multicolumn{2}{|c|}{3696} \\
\hline Ether extract & \multicolumn{2}{|c|}{3.61} & \multicolumn{2}{|c|}{1.66} & \multicolumn{2}{|c|}{21.87} & \multicolumn{2}{|c|}{2.57} \\
\hline Crude fiber & \multicolumn{2}{|c|}{1.73} & \multicolumn{2}{|c|}{5.41} & \multicolumn{2}{|c|}{1.25} & \multicolumn{2}{|c|}{1.07} \\
\hline Calcium & \multicolumn{2}{|c|}{0.03} & \multicolumn{2}{|c|}{0.24} & \multicolumn{2}{|c|}{0.49} & \multicolumn{2}{|c|}{0.03} \\
\hline Available phosphorus & \multicolumn{2}{|c|}{0.08} & \multicolumn{2}{|c|}{0.18} & \multicolumn{2}{|c|}{0.06} & \multicolumn{2}{|c|}{0.15} \\
\hline Sodium & & & & & & & & \\
\hline & $\mathrm{TAA}^{1}$ & $\mathrm{DAA}^{2}$ & TAA & DAA & TAA & DAA & TAA & DAA \\
\hline Total alanine & 0.59 & 0.55 & 1.94 & 1.90 & 5.52 & 5.48 & 5.38 & 5.34 \\
\hline Total arginine & 0.36 & 0.33 & 3.19 & 3.06 & 7.60 & 7.37 & 1.96 & 1.89 \\
\hline Total glycine & 0.31 & 0.30 & 1.89 & 1.88 & 31.13 & 31.12 & 1.70 & 1.69 \\
\hline Total isoleucine & 0.27 & 0.24 & 2.01 & 1.83 & 1.80 & 1.75 & 2.51 & 2.36 \\
\hline Total leucine & 0.97 & 0.92 & 3.42 & 3.12 & 3.40 & 3.29 & 9.68 & 9.41 \\
\hline Total lysine & 0.23 & 0.20 & 2.72 & 2.50 & 4.40 & 4.27 & 1.05 & 0.96 \\
\hline Total cystine & 0.18 & 0.16 & 0.62 & 0.60 & 0.22 & 0.20 & 1.07 & 1.05 \\
\hline Total methionine & 0.17 & 0.16 & 0.60 & 0.54 & 0.74 & 0.72 & 1.43 & 1.38 \\
\hline Total methionine + cystine & 0.35 & 0.32 & 1.22 & 1.06 & 0.84 & 0.81 & 2.49 & 2.31 \\
\hline Total phenylalanine & 0.39 & 0.35 & 2.32 & 2.15 & 2.06 & 1.99 & 3.93 & 3.73 \\
\hline Total tyrosine & 0.24 & 0.21 & 1.50 & 1.47 & 0.37 & 0.34 & 3.00 & 3.97 \\
\hline Total threonine & 0.29 & 0.24 & 1.74 & 1.53 & 1.70 & 1.65 & 2.08 & 1.92 \\
\hline Total tryptophan & 0.06 & 0.05 & 0.58 & 0.52 & - & - & 0.34 & 0.31 \\
\hline Total valine & 0.39 & 0.34 & 2.13 & 1.90 & 2.80 & 2.72 & 2.82 & 2.65 \\
\hline Total histidine & 0.24 & 0.22 & 1.16 & 1.10 & 0.95 & 0.92 & 1.30 & 1.22 \\
\hline Total serine & 0.39 & 0.34 & 2.29 & 2.24 & 3.43 & 3.38 & 3.16 & 3.11 \\
\hline
\end{tabular}

${ }^{1}$ Total amino acids, determined by Degussa Laboratory - Animal Nutrition Service - São Paulo, SP/Brazil

${ }^{2}$ Digestible amino acids, calculated based on digestibility coefficients of the Brazilian Tables for Poultry and Swine (2005)

${ }^{3}$ GELITA ${ }^{\circledR}$, Gelita do Brasil Ltda. Leiner Phillip 200 Street, CEP 06714-285, Cotia, SP/Brazil.

${ }^{4}$ Corn Products Brazil - Industrial Ingredients Ltda. 
The basal diet (Table 2) was formulated to contain $0.1395 \%$ of digestible tryptophan, accounting for $13 \%$ of the 1.0735 digestible lysine level, and the other diets with increasing levels of $2 \%$ in relation to the basal diet, which contained $0.1610,0.1825,0.2040,0.2255$ and 0.2470 - that is, two levels below and three levels above the $0.1825 \%$ recommended by Rostagno et al. (2005). The levels of lysine, methionine + cystine and other amino acids used in the diet formulation were established by Rostagno et al. (2005).

L-tryptophan was added to the basal diet to replace L-glutamic acid, so as to keep all treatments with the same level of nitrogen and eliminate any effects related to differences in their concentration. Thus, diets with low levels of tryptophan contained higher levels of L-glutamic acid.

The birds were weighed at the beginning and end of the experiment to determine weight gain, by the difference of weight at 21 and 42 days of age. Likewise, feed intake was obtained by the difference between the feed provided and the feed left over in the troughs. Subsequently, feed conversion was calculated as the ratio between feed intake and bird weight gain. Viability (VC) was determined as the total number of birds housed minus birds that died or were removed from the experimental unit, divided by the total number of birds housed (multiplied by 100).

To calculate the production efficiency index $(\mathrm{PEI}=$ [average daily weight gain $(\mathrm{g}) \times \mathrm{VC}(\%)] /($ feed conversion $\times 10$ ), average weight gain, feed intake and feed conversion of the birds were considered at that age. This averaging was performed because all birds received the same diet during the first 22 days of age, when they were weighed and selected for early experimental period.

At the end of the experimental period, eight birds per experimental unit with body weight near the average of

Table 2 - Percentage composition of the experimental diets for broilers from 22 to 42 days old

\begin{tabular}{|c|c|c|c|c|c|c|}
\hline \multirow{2}{*}{ Ingredients (g/100 g) } & \multicolumn{6}{|c|}{ Digestible tryptophan levels } \\
\hline & 0.1395 & 0.1610 & 0.1825 & 0.2040 & 0.2255 & 0.2470 \\
\hline Corn & 66.295 & 66.295 & 66.295 & 66.295 & 66.295 & 66.295 \\
\hline Soybean meal & 21.365 & 21.365 & 21.365 & 21.365 & 21.365 & 21.365 \\
\hline Corn gluten meal $60 \%$ & 4.580 & 4.580 & 4.580 & 4.580 & 4.580 & 4.580 \\
\hline Gelatin & 1.500 & 1.500 & 1.500 & 1.500 & 1.500 & 1.500 \\
\hline Soybean oil & 1.965 & 1.965 & 1.965 & 1.965 & 1.965 & 1.965 \\
\hline Dicalcium phosphate & 1.642 & 1.642 & 1.642 & 1.642 & 1.642 & 1.642 \\
\hline Limestone & 0.973 & 0.973 & 0.973 & 0.973 & 0.973 & 0.973 \\
\hline L-glutamic acid (99\%) & 0.1621 & 0.1297 & 0.0973 & 0.0648 & 0.0324 & 0.000 \\
\hline L-lysine $(78.5 \%)$ & 0.290 & 0.290 & 0.290 & 0.290 & 0.290 & 0.290 \\
\hline DL-methionine (99\%) & 0.141 & 0.141 & 0.141 & 0.141 & 0.141 & 0.141 \\
\hline L-tryptophan (98\%) & 0.000 & 0.0215 & 0.043 & 0.0645 & 0.086 & 0.1075 \\
\hline L-threonine (98\%) & 0.1234 & 0.1234 & 0.1234 & 0.1234 & 0.1234 & 0.1234 \\
\hline L-arginine (99\%) & 0.000 & 0.000 & 0.000 & 0.000 & 0.000 & 0.000 \\
\hline L-valine $(96.5 \%)$ & 0.014 & 0.014 & 0.014 & 0.014 & 0.014 & 0.014 \\
\hline L-isoleucine (99\%) & 0.000 & 0.000 & 0.000 & 0.000 & 0.000 & 0.000 \\
\hline Vitamin + mineral supplementation ${ }^{1}$ & 0.500 & 0.500 & 0.500 & 0.500 & 0.500 & 0.500 \\
\hline Salt & 0.449 & 0.449 & 0.449 & 0.449 & 0.449 & 0.449 \\
\hline Inert (washed sand) & 0.000 & 0.0109 & 0.0218 & 0.0328 & 0.0437 & 0.0546 \\
\hline Total & 100.00 & 100.00 & 100.00 & 100.00 & 100.00 & 100.00 \\
\hline \multicolumn{7}{|c|}{ Calculated values } \\
\hline Crude protein $(\mathrm{g} / 100 \mathrm{~g})$ & 20.11 & 20.11 & 20.11 & 20.11 & 20.11 & 20.11 \\
\hline Metabolizable energy (kcal/kg) & 3,175 & 3,175 & 3,175 & 3,175 & 3,175 & 3,175 \\
\hline Calcium (g/100 g) & 0.874 & 0.874 & 0.874 & 0.874 & 0.874 & 0.874 \\
\hline Sodium (g/100 g) & 0.210 & 0.210 & 0.210 & 0.210 & 0.210 & 0.210 \\
\hline Total phosphorus (g/100 g) & 0.628 & 0.6282 & 0.6282 & 0.6282 & 0.6282 & 0.6282 \\
\hline Available phosphorus (g/100 g) & 0.406 & 0.406 & 0.406 & 0.406 & 0.406 & 0.406 \\
\hline Digestible lysine (g/100 g) & 1.0735 & 1.0735 & 1.0735 & 1.0735 & 1.0735 & 1.0735 \\
\hline Digestible methionine (g/100 g) & 0.4663 & 0.4663 & 0.4663 & 0.4663 & 0.4663 & 0.4663 \\
\hline Digestible methionin + cystine $(\mathrm{g} / 100 \mathrm{~g})$ & 0.773 & 0.773 & 0.773 & 0.773 & 0.773 & 0.773 \\
\hline Digestible tryptophan $(\mathrm{g} / 100 \mathrm{~g})^{2}$ & 0.1395 & 0.1610 & 0.1825 & 0.2040 & 0.2255 & 0.2470 \\
\hline Digestible threonine $(\mathrm{g} / 100 \mathrm{~g})^{3}$ & 0.7642 & 0.7642 & 0.7642 & 0.7642 & 0.7642 & 0.7642 \\
\hline Digestible arginine $(\mathrm{g} / 100 \mathrm{~g})$ & 1.127 & 1.127 & 1.127 & 1.127 & 1.127 & 1.127 \\
\hline Digestible valine $(\mathrm{g} / 100 \mathrm{~g})$ & 0.821 & 0.821 & 0.821 & 0.821 & 0.821 & 0.821 \\
\hline Digestible isoleucine $(\mathrm{g} / 100 \mathrm{~g})$ & 0.719 & 0.719 & 0.719 & 0.719 & 0.719 & 0.719 \\
\hline
\end{tabular}

${ }^{1}$ Enrichment per kilogram of diet: vitamin A - 8,000 IU; vitamin D3 - 1,800 IU; vitamin E - 12 mg; vitamin K3 - 2 mg; vitamin B1 - 1 mg; vitamin B2 - 4 mg; vitamin B6 - 1 mg; vitamin B12 - $10 \mathrm{mcg}$; folic acid - $0.40 \mathrm{mg}$; biotin - $0.04 \mathrm{mg}$; niacin - $28 \mathrm{mg}$; calcium pantothenate - $11 \mathrm{mg}$; $\mathrm{Cu}-6 \mathrm{mg}$; $\mathrm{Co}-0.10 \mathrm{mg}$; I - $1 \mathrm{mg}$; Fe - $50 \mathrm{mg}$; Mn - $65 \mathrm{mg}$; $\mathrm{Zn}-45 \mathrm{mg}$; $\mathrm{Se}-0.21 \mathrm{mg}$; choline chloride $50 \%-500 \mathrm{mg}$; coccidiostat - $60 \mathrm{mg}$; antioxidant $-12 \mathrm{mg}$.

${ }^{2}$ The $0.1825(\mathrm{~g} / 100 \mathrm{~g})$ level of digestible tryptophan was recommended by Rostagno et al. (2005).

${ }^{3}$ The $0.7642(\mathrm{~g} / 100 \mathrm{~g})$ level of digestible threonine was recommended by Duarte (2009). 
the plot were selected and feed-deprived for 6 hours, then sacrificed by jugular bleeding, plucked and eviscerated. After weighing the carcass, they were cut to evaluate carcass yield (excluding head, neck and feet), breast yield, thigh + drumstick yield, wing yield and back yield.

Statistical analyses were performed using the SAS software (Statistical Analysis System, version 9.2). In the case of statistical significance, the comparison of means was also adopted using Duncan's test at $5 \%$ of probability. To determine digestible tryptophan requirements, three regression models were used: the quadratic model described by Robbins et al. (1979), the exponential model described by Noll \& Waibel (1989) and the Linear Plateau Response (LRP) described by Braga (1983) with 90\% maximum square, according to the best fit obtained for each variable studied.

\section{Results and Discussion}

Digestible tryptophan levels did not influence the studied variables $(\mathrm{P}>0.05$; Table 3$)$. No appropriate fit was obtained the by the quadratic, exponential or LRP models for bird performance data, since these models were not significant $(\mathrm{P}>0.05)$ by regression analysis of variance. The equations obtained from regression analyses in this study were not reliable for obtaining an optimal digestible tryptophan level in the analyzed variables. Given the nonsignificant $(\mathrm{P}>0.05)$ effect of digestible tryptophan levels on these variables, the means were compared by the Duncan test at $5 \%$ of probability. Although there was no difference between the evaluated levels, it can be inferred that the $0.2255 \%$ digestible tryptophan level indicated numerical improvement in feed conversion (Table 3), disagreeing with the $0.18 \%$ suggested by NRC (1994) and Rostagno et al. (2005) for broilers from 22 to 42 days of age.

According to Rosebrough (1996), diets with low protein levels (12\%) supplemented with tryptophan excess caused a reduction in feed intake, which did not happen with diets high in crude protein (30\%) for 28-day-old male broilers. In this experiment, the digestible tryptophan levels did not significantly affect feed intake, even when using the low level $(0.1395$ and $0.1610 \%)$ when compared with the level of $0.1825 \%$ recommended by Rostagno et al. (2005). This effect may be due to the appropriate level of crude protein of experimental diets $(20.11 \%)$. Numerically, the level of $0.1825 \%$ promoted greater feed intake, which decreased at higher levels of supplementation. Edmonds \& Baker (1987) found that a $4 \%$ excess of tryptophan reduced the weight gain of broilers by $57 \%$.
Results obtained by Warnick \& Anderson (1968) and Rogers \& Pesti (1990), also using broilers, indicated that tryptophan-deficient diets caused a reduction in weight gain. Moreover, Koelkebeck et al. (1991) found that excess tryptophan in the diet resulted in lower weight gain for layer hens. These authors also observed that the effect of excess tryptophan on the reduction of weight gain was more evident than excess methionine. Although they did not show a significant effect of digestible tryptophan levels, the data obtained in this experiment also indicated that excess tryptophan caused a numerical decrease in bird weight gain. According to Leeson (1995) and Si et al. (2001), broilers fed diets marginal in amino acids increase feed intake to meet their weight gain requirements. According to Teeter et al. (1993), the standard and the amount of amino acid consumed by the birds have a great influence on weight gain and feed intake.

In the present study, the best digestible lysine level of the experimental diets was $1.0735 \%$, considering the $90.7 \%$ digestibility coefficient of lysine (Rostagno et al., 1996), and the best digestible tryptophan level found for feed conversion was $0.2255 \%$. According to this information, the ratio of digestible tryptophan to digestible lysine, within the ideal protein concept, was approximately $21.00 \%$, higher than the $16.6 \%$ level suggested by Baker et al. (2002) and the $17 \%$ recommended by Rostagno et al. (2005).

Except for carcass yield (Table 4), it was not possible to describe the behavior of the data through the regression models proposed. Due to the non-significant effect $(\mathrm{P}>0.05)$ of digestible tryptophan levels on the other variables and/or low determination coefficients found with the regression analyses proposed, the means were compared using the Duncan test at $5 \%$ of probability.

The digestible tryptophan levels did not significantly affect the yield of breast, thigh and drumstick, back and wings ( $\mathrm{P}>0.05$; Table 4). However, there was a quadratic effect of digestible tryptophan levels on carcass yield $(\mathrm{P}<0.05)$, whose requirement estimated through quadratic regression model was $0.1919 \%$ (Table 5; Figure 1).

The ratios of digestible tryptophan to digestible lysine, within the ideal protein concept, were approximately $17.88 \%$ and $17.00 \%$ using the quadratic model and the Duncan test at $5 \%$ probability, respectively, agreeing with the results of Corzo et al. (2005) and Rostagno et al. (2005). In an experiment using $0.09,0.12,0.15,0.18,0.21,0.24$, 0.27 and $0.30 \%$ of tryptophan levels in the diet of Cobb broilers, Freeman (1979) concluded that the requirements for males and females from 7 to 35 days of age were $0.17 \%$ for both sexes. 
Table 3 - Performance of broilers fed diets containing different digestible tryptophan levels from 22 to 42 and 1 to 42 days of age

\begin{tabular}{|c|c|c|c|c|c|}
\hline \multirow{2}{*}{$\begin{array}{l}\text { Digestible tryptophan } \\
\text { levels }(\mathrm{g} / 100 \mathrm{~g})\end{array}$} & \multicolumn{5}{|c|}{ Performance } \\
\hline & Feed intake $(\mathrm{kg})$ & Weight gain $(\mathrm{kg})$ & Feed conversion $(\mathrm{kg} / \mathrm{kg})$ & Viability $^{1}(\%)$ & $\begin{array}{c}\text { Production efficiency } \\
\text { index ( } 1-42 \text { days of age })\end{array}$ \\
\hline 0.1395 & 3.484 & 1.849 & 1.884 & 97.50 & 365.52 \\
\hline 0.1610 & 3.479 & 1.847 & 1.883 & 97.92 & 364.90 \\
\hline 0.1825 & 3.495 & 1.859 & 1.881 & 96.25 & 365.41 \\
\hline 0.2040 & 3.409 & 1.838 & 1.856 & 94.58 & 364.00 \\
\hline 0.2255 & 3.419 & 1.859 & 1.840 & 96.67 & 364.00 \\
\hline 0.2470 & 3.428 & 1.821 & 1.881 & 94.17 & 365.03 \\
\hline P-value & $0.2686 \mathrm{NS}$ & $0.7486 \mathrm{NS}$ & $0.2335 \mathrm{NS}$ & $0.2189 \mathrm{NS}$ & $0.2239 \mathrm{NS}$ \\
\hline F-value & 1.33 & 0.53 & 1.43 & 1.47 & 1.03 \\
\hline $\mathrm{CV}(\%)$ & 2.68 & 3.00 & 2.37 & 3.69 & 3.49 \\
\hline
\end{tabular}

NS - not significant.

${ }^{1}$ Number of birds slaughtered.

Table 4 - Body measurements of broilers fed diets containing different digestible tryptophan levels from 22 to 42 days of age

\begin{tabular}{|c|c|c|c|c|c|}
\hline \multirow{2}{*}{$\begin{array}{l}\text { Digestible tryptophan } \\
\text { levels }(\mathrm{g} / 100 \mathrm{~g})\end{array}$} & \multicolumn{5}{|c|}{ Carcass yield $^{1}$} \\
\hline & Carcass yield (\%) & Breast yield (\%) & Thigh + drumstick yield $(\%)$ & Back yield (\%) & Wing yield $(\%)$ \\
\hline 0.1395 & 72.91 & 36.23 & 30.55 & 22.25 & 10.67 \\
\hline 0.1610 & 73.17 & 36.52 & 30.40 & 21.51 & 10.72 \\
\hline 0.1825 & 74.04 & 36.63 & 29.92 & 21.61 & 10.56 \\
\hline 0.2040 & 73.48 & 36.30 & 30.04 & 22.14 & 10.59 \\
\hline 0.2255 & 73.05 & 36.23 & 29.93 & 21.90 & 10.64 \\
\hline 0.2470 & 72.98 & 36.02 & 30.75 & 22.14 & 10.47 \\
\hline P-value & $0.0479 *$ & $0.9404 \mathrm{NS}$ & $0.4104 \mathrm{NS}$ & $0.4869 \mathrm{NS}$ & $0.4180 \mathrm{NS}$ \\
\hline F-value & 2.07 & 0.24 & 1.03 & 0.90 & 1.02 \\
\hline $\mathrm{CV}(\%)$ & 1.14 & 3.45 & 3.23 & 4.14 & 2.42 \\
\hline
\end{tabular}

Means in the column followed by different letters differ $(\mathrm{P}<0.05)$ by the Duncan test.

${ }^{1}$ Eviscerated carcass without feet, head and neck.

NS - not significant.

$* \mathrm{P}<0.05$.

Table 5 - Adjusted equation for carcass yield (CY), according to digestible tryptophan levels, determination coefficients $\left(\mathrm{R}^{2}\right)$ and estimated digestible tryptophan level (Ntrip) using the quadratic model

\begin{tabular}{lcccc}
\hline Regression model & Variable/equation & NTrip (\%) & $\mathrm{R}^{2}$ \\
\hline Quadratic & $\mathrm{CY}=-266.64 \times \mathrm{Ntrip}^{2}+102.32 \times \mathrm{Ntrip}+63.813$ & 0.1919 & 0.54 \\
\hline
\end{tabular}

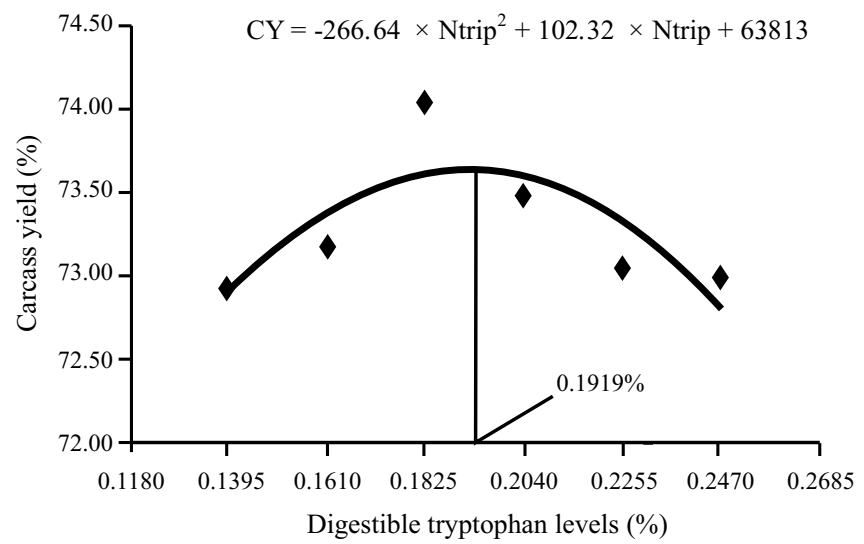

CY - carcass yield; Ntrip - estimated digestible tryptophan.

Figure 1 - Adequate digestible tryptophan level to maximize carcass yield, estimated by the quadratic equation for broilers from 22 to 42 days of age.

\section{Conclusions}

The level of $0.2255 \%$ of digestible tryptophan numerically improves feed conversion, and the level of $0.1919 \%$ estimated by the quadratic equation improves carcass yield, corresponding to a digestible tryptophan:digestible lysine rate of $21.00 \%$ for feed conversion and $17.00 \%$ for carcass yield.

\section{Acknowledgments}

The authors thank FAPESP for the research assistance and the fellowship granted.

\section{References}

BAKER, D.H.; BATAL, A.B.; PARR, T.M. et al. Ideal ratio (relative to lysine) of tryptophan, threonine, isoleucine, and valine for chicks 
during the second and third weeks posthatch. Poultry Science, v.81, p.485-494, 2002.

BRAGA, J.M. Avaliação da fertilidade do solo (ensaios de campo). Viçosa, MG: UFV, 1983. 101p.

COLNAGO, L.G. Aminoácidos em rações de frangos e matrizes pesadas. In: CONFERÊNCIA DE CIÊNCIA E TECNOLOGIA AVÍCOLAS, Santos, 1992. Anais... Santos: FACTA, 1992. p.45-54.

CORZO, A.; MORAN Jr., E.T.; HOEHLER, D. et al. Dietary tryptophan need of broiler males from forty-two to fifty-six days of age. Poultry Science, v.84, p.226-231, 2005.

DUARTE, K.F. Critérios de avaliação das exigências em treonina, triptofano, valina e isoleucina para frangos de corte de 22 a 42 dias de idade. 2009. 118f. Tese (Doutorado em Zootecnia) Universidade Estadual Paulista/Faculdade de Ciências Agrárias e Veterinárias, Jaboticabal.

EDMONDS, M.S.; BAKER, D.H. Comparative effects of individual amino acid excesses when added to a corn-soybean meal diet: effects on growth and dietary choice in the chick. Journal of Animal Science, v.65, p.699-705, 1987.

FREEMAN, C.P. The tryptophan requirement of broiler chicks. British Poultry Science, v.20, p.27-37, 1979.

HENRY, Y.; SÈVE, B.; COLLÉAUX, Y. et al. Interactive effects of dietary levels of tryptophan and protein on voluntary feed intake an growth performance in pigs, in relation to plasma free amino acids and hypothalamic serotonin. Journal of Animal Science, v.70, p.1873-1887, 1992.

KIDD, M.T.; HACKENHAAR, L. Dietary threonine for broilers: dietary interactions and feed additive supplement use. CAB Reviews: Perspectives in Agriculture, Veterinary Science, Nutrition and Natural Resources, v.1, n.5, 6p, 2006.

KOELKEBECK, K.W.; BAKER, D.H.; HAN, Y. et al. Research note: effect of excess lysine, methionine, threonine, or tryptophan on production performance of laying hens. Poultry Science, v.70, p.1651-1653, 1991.

LEESON, S. Nutrição e qualidade de carcaça de frangos de corte. In: COFERÊNCIA APINCO DE CIÊNCIA E TECNOLOGIA AVÍCOLAS, Curitiba, 1995. Anais... Curitiba, 1995. p.111-118.

NATIONAL RESEARCH COUNCIL - NRC. Nutrients requirements of poultry. 9.ed. Washington, D.C.: National Academy Press, 1994. $155 \mathrm{p}$.
NOLL, S.L.; WAIBEL, P.E. Lysine requirement of the growing turkey in various temperature environments. Poultry Science, v.68, p.781-794, 1989.

PEGANOVA, S.; HIRCHE, F.; EDER, K. Requirement of tryptophan in relation to the supply of large neutral amino acids in laying hens. Poultry Science, v.82, p.815-822, 2003.

PUPA, J.M.R. Rações para frangos de corte formuladas com valores de aminoácidos digestíveis verdadeiros, determinados com galos cecectomizados. 1995. 63f. Dissertação (Mestrado em Zootecnia) - Universidade Federal de Viçosa, Viçosa, MG.

ROBBINS, K.R.; NORTON, H.W.; BAKER, D.H. Estimation of nutrient requirements from growth data. The Journal of Nutrition, v.109, p.1710-1714, 1979.

ROGERS, S.R.; PESTI, G.M. The influence of dietary tryptophan on broiler chick growth and lipid metabolism as mediated by dietary protein levels. Poultry Science, v.69, p.746-756, 1990.

ROSEBROUGH, R.W. Crude protein and supplemental dietary tryptophan effects on growth and tissue neurotransmitter levels in the broiler chicken. British Journal of Nutrition, v.76, p.87-96, 1996.

ROSTAGNO, H.S.; ALBINO, L.F.T.; DONZELE, J.L. et al. Tabelas brasileiras para aves e suínos: composição de alimentos e exigências nutricionais. Viçosa, MG: UFV, 1996. 141p.

ROSTAGNO, H.S.; ALBINO, L.F.T.; DONZELE, J.L. et al. Tabelas brasileiras para aves e suínos: composição de alimentos e exigências nutricionais. 2.ed. Viçosa, MG: UFV, Departamento de Zootecnia, 2005. 186p.

SI, J.; FRITTS, C.A.; BURNHAM, D.J. et al. Relationship of dietary lysine level to the concentration of all essential amino acids in broiler diets. Poultry Science, v.80, p.1472-1479, 2001.

SILVA, D.J. Análise de alimentos: métodos químicos e biológicos. Viçosa, MG: UFV, Imprensa Universitária, 1990. 160p.

TEETER, R.G.; BELAY, T.; WIERNUSZ, C.J. Poultry nutrition research. In: ANNUAL PFIZER RESEARCH CONFERENCE, 41., 1992, New York. Proceedings... New York: Pfizer, 1993. p. $170-274$

WARNICK, R.E.; ANDERSON, J.O. Limiting essential amino acids in soybean meal for growing chickens and the effects of heat upon availability of the essential amino acids. Poultry Science, v.47, p.281-287, 1968. 